\title{
Mechanical Harvesting and Dehulling of Six Strawberry Cultivars after Four Hand-pickings
}

\author{
Shahrokh Khanizadeh ${ }^{1}$ \\ Agriculture Canada Research Station, 430 Boulevard Gouin, St-Jean-sur- \\ Richelieu, Que. J3B 3E6, Canada, and Department of Plant Science, McGill \\ University, Ste-Anne-de-Bellevue, Que. H9X 3V9, Canada
}

Michel J. Lareau ${ }^{2}$

Agriculture Canada Research Station, 430 Boulevard Gouin, St-Jean-surRichelieu, Que. J3B 3E6, Canada

\section{Deborah Buszard ${ }^{3}$ \\ Department of Plant Science, McGill University, Ste-Anne-de-Bellevue, Que. H9X 3V9, Canada}

Additional index words. Fragaria $\times$ ananassa, fruit size, processing, breeding

\begin{abstract}
An experiment was conducted to evaluate the mechanical harvesting and processing suitability of four standard strawberry [Fragaria $\times$ ananassa $($ Duch.)] cultivars ('Kent', 'Glooscap', 'Bounty', and 'Midway') and the recent introductions 'Chambly' and 'Oka'. 'Kent', 'Glooscap', 'Oka', and 'Chambly' had the highest yields and heaviest fruit. Similar percentages of berries of all cultivars were destroyed by the harvester. 'Oka' and 'Midway' were not suitable for this type of mechanical harvesting due to their susceptibility to bruising during harvest. Based on total marketable fruit harvested mechanically, 'Chambly' was the most and 'Oka' was the least adapted cultivars for this particular harvester. 'Chambly' and 'Glooscap' were easiest to decap, followed by 'Bounty', 'Oka', and 'Midway'. None of the cultivars tested were suited ideally for machine harvesting, and further breeding is required to produce well-adapted cultivars.
\end{abstract}

Canada imports 40,000 t of strawberries annually, of which $\approx 7000 \mathrm{t}$ are frozen berries used for processing and are worth more than \$6.5 million (Can. \$9 million). These imports could be replaced by Canadian-grown fruit if improved cultivars, suitable for mechanical harvesting and processing and adapted to Canada's wide variety of climatic conditions, were available. Despite Quebec's position as a strawberry-growing region that produces onethird $(10,000 \mathrm{t})$ of the total Canadian production [about \$3.7 million (Can. \$50 million) (Statistics Canada, 1991)], Quebec produces almost no strawberries for processing. Most Canadian-grown processing berries are produced in British Columbia. In 1991, the Quebec processing industry used $3000 \mathrm{t}$ of imported frozen berries and pulp that could have been grown by local producers.

Received for publication 29 Nov. 1993. Accepted for publication 10 Sept. 1994. Agriculture Canada contribution no. 3. We thank Michel Johnson, Susan Féchette, and C. Guy-Adam for their technical assistance. This study was supported by research grant 1A1-675200117-003 from Entente Auxiliaire Canada-Quebec. The cost of publishing this paper was defrayed in part by the payment of page charges. Under postal regulations, this paper therefore must be hereby marked advertisement solely to indicate this fact.

${ }^{1}$ Assistant Professor and Research Scientist, Breeder, Physiologist.

${ }^{2}$ Research Scientist, Small Fruit Specialist.

${ }^{3}$ Associate Professor, Research Horticulturist.
Mechanical harvesting and dehulling is a necessity in areas where there are labor shortages or where there is no outlet for smaller, pick-your-own or fresh-picked wholesale berries. There have been many attempts to develop strawberry harvesters (Booster, 1980; Hansen and Ledebuhr, 1980), and researchers have studied the feasibility (Lauro, 1986) and cost of mechanically harvesting strawberries (Seecharan et al., 1988). Several harvesters have been developed, and some of them have been commercialized (Hansen and Ledebuhr, 1980; Hecht, 1972; Morris et al., 1978). In most cases, it is necessary to have a flat, level bed to present the fruit to the harvester on a flat plane. Although once-over harvesting is often preferred (Dale, 1983; Ricketson, 1969), most producers would like to hand-pick early, highquality, large fruit and only use a harvester for the later small fruit. Small berries are well suited to machine harvesting; large berries bruise more easily (Denisen and Buchele, 1967). Certain plant characteristics are prerequisites for successful mechanical harvesting: 1) brittle pedicels, 2) easy decapping, 3) concentrated ripening, and 4) firm fruit (Khanizadeh and Fanous, 1992; Khanizadeh et al., 1992b). Breeding programs select for these characteristics in an attempt to produce cultivars adapted to mechanical harvesting

Our study was conducted to determine if it is feasible to harvest the crop portion that often remains unharvested after three to four hand- pickings and to evaluate suitability for mechanical harvesting and dehulling (decapping) of the two recently released cultivars Chambly and Oka (Khanizadeh, 1994; Khanizadeh et al., 1990, 1992c) compared to four standard cultivars.

\section{Materials and Methods}

The experiments were conducted at Lavaltrie, Quebec (lat. $45^{\circ} \mathrm{N}$ ), and at a 46-m altitude in a sandy soil and a continental climate. A randomized complete-block design with four replications was used to evaluate the four standard cultivars ('Kent', 'Glooscap', 'Bounty', and 'Midway') and the recent introductions 'Chambly' and 'Oka'. The field was prepared in 1990 and leveled to present the fruit to the harvester on a flat plane. Plants were set $30 \mathrm{~cm}$ apart in a single row in $30-\mathrm{m}-$ long plots, spaced $120 \mathrm{~cm}$ apart and watered immediately with $250 \mathrm{ml}$ of a fertilizer solution $(10 \mathrm{~N}-52 \mathrm{P}-10 \mathrm{~K})$ per plant. Flowers were removed twice, and all runners kept and spaced within the 50-cm-wide matted row. In November, the plants were mulched with straw to a depth of 6 to $7 \mathrm{~cm}$ for winter protection. In early spring of each year, the rows were rolled to level the surface. 'Chambly', 'Glooscap', Kent', and 'Midway' (early and midseason cultivars) were hand-harvested on 18,21, and 25 June, followed by a once-over machine harvest on 27 June. 'Oka' (an early midseason cultivar) was hand-harvested on 18, 21, 25, and 27 June, followed by a once-over machine harvest on 7 July. 'Bounty' (a late cultivar) was hand-harvested on 21, 25, and 27 June, followed by a once-over machine harvest on 7 July. A similar schedule was used in 1992; however, the harvest started 2 days earlier. The strawberry harvester used in our trials was a tractor-drawn prototype (Khanizadeh et al., 1994).

In each hand-harvest, we collected fruit from a 30-m-long bed in each block. Average fruit weight was calculated by averaging the weights of 50 randomly selected fruit in each harvest.

Berries were decapped on an older Canners Machinery model. For this type of decapper, berries must have a weak stem-end and calyx attachment like those in 'Glooscap' and 'Chambly'. In operation, washed strawberries move onto a conveyor, and a series of horizontally rotating rubber rollers grab and pull the calyx and stem end.

Data collected for each hand-harvest were combined for analysis of variance (ANOVA). Before ANOVA, percentage data were transformed using an arcsin, square-root, percent transformation. The ANOVA were done using the general linear model procedure (SAS, 1988). Least significant difference was used for mean separation between the cultivars.

\section{Results and Discussion}

Yields were similar in 1991 and 1992 (data not shown). 'Kent', 'Glooscap', 'Oka', and 'Chambly' had the highest field and fruit weights, but fruit weights were similar for 

'Bounty' and 'Midway' had poor yields, and 'Midway' also had low-weight fruit. 'Kent', 'Glooscap', and 'Chambly' produced the highest total marketable yield over all harvests (i.e., three or four hand-pickings + machineharvested fruit).

Because there were differences between cultivars in terms of total yield, earliness, and concentration of ripening (Khanizadeh et al., 1992a), different quantities of berries were left in the field after the four hand-pickings. Due to its different production schedule, higher percentages of 'Bounty' strawberries were left in the field available to be mechanically picked, followed by 'Kent', 'Glooscap', and 'Chambly'.

To compare cultivar suitability for mechanical harvesting, an ANOVA was performed on the percentage of fruit left in the field after machine harvest. Similar percentages of berries of all cultivars were destroyed
'Bounty', 'Chambly', and 'Kent' (Table 1).

by the harvester (Table 2). 'Oka' and 'Midway' were not suitable for this type of mechanical harvesting due to their susceptibility to bruising during harvesting (Table 2). The percentage of nonmarketable fruit following mechanical harvesting did not differ significantly among cultivars, although 'Glooscap' had a lower percentage than the others (Table 2).

Based on total marketable fruit harvested mechanically, 'Chambly' was the most and 'Oka' was the least adapted cultivar for this particular harvester.

Because of insufficient fruit counts from each replication, mechanically harvested fruit from all the replications of a single cultivar were mixed before decapping. All the cultivars had a high proportion of berries with green stem ends (partially decapped) (Table 3 ). The proportion of partially decapped berries was high for 'Kent', 'Chambly', and

Table 1. Total yield and fruit weight of the six strawberry cultivars that were hand-picked and that remained for a mechanical harvester in Lavaltrie, Quebec, Canada, 1991 and 1992. ${ }^{2}$

\begin{tabular}{|c|c|c|c|c|c|}
\hline \multirow[b]{2}{*}{ Cultivar } & \multicolumn{2}{|c|}{ Hand-picking } & \multirow{2}{*}{$\begin{array}{c}\text { Berries remaining } \\
\text { for mechanical } \\
\text { harvesting }\end{array}$} & \multicolumn{2}{|c|}{$\begin{array}{l}\text { Hand-picked + mechanical } \\
\text { harvesting yield }\end{array}$} \\
\hline & Yield & fruit wt (g) & & Nonmarketable & Marketable \\
\hline Bounty & $12.5 \mathrm{~b}$ & $9.5 \mathrm{bc}$ & $12.8 \mathrm{a}$ & 3.9 & $18.7 \mathrm{c}$ \\
\hline Chambly & $20.9 \mathrm{a}$ & $10.1 \mathrm{ab}$ & $7.1 \mathrm{bc}$ & 5.9 & $24.1 \mathrm{a}-\mathrm{c}$ \\
\hline Glooscap & $23.9 \mathrm{a}$ & $11.8 \mathrm{a}$ & $10.3 \mathrm{ab}$ & 4.4 & $29.8 \mathrm{a}$ \\
\hline Kent & $24.6 \mathrm{a}$ & $11.3 \mathrm{ab}$ & $11.0 \mathrm{ab}$ & 7.0 & $28.6 \mathrm{ab}$ \\
\hline Midway & $7.8 \mathrm{~b}$ & $8.4 \mathrm{c}$ & $5.8 \mathrm{c}$ & 4.2 & $9.4 \mathrm{~d}$ \\
\hline Oka & $21.0 \mathrm{a}$ & $12.2 \mathrm{a}$ & $5.3 \mathrm{c}$ & 4.0 & $22.3 \mathrm{bc}$ \\
\hline $\mathrm{LSD}_{0.01}$ & 5.4 & 2.9 & 4.3 & NS & 7.4 \\
\hline
\end{tabular}

${ }^{\mathrm{z}}$ Average of four replications.

${ }^{y}$ Yields in kilograms per $30 \mathrm{~m}$ of row.

Table 2. Fruit ripeness and marketability of six strawberry cultivars after using a harvester, 1991 and $1992 .{ }^{2}$

\begin{tabular}{|c|c|c|c|c|c|c|c|}
\hline \multirow[b]{3}{*}{ Cultivar } & \multicolumn{3}{|c|}{$\begin{array}{c}\text { Berries harvested } \\
\text { mechanically }\end{array}$} & \multicolumn{3}{|c|}{$\begin{array}{l}\text { Berries remaining } \\
\text { after using harvester }\end{array}$} & \multirow{3}{*}{$\begin{array}{c}\text { Fruit destroyed } \\
\text { by harvester } \\
(\%)\end{array}$} \\
\hline & \multicolumn{2}{|c|}{ Marketable (\%) } & \multirow[b]{2}{*}{ Bruised } & \multicolumn{2}{|c|}{ Marketable (\%) } & \multirow{2}{*}{$\begin{array}{c}\text { Nonmarketable } \\
(\%)\end{array}$} & \\
\hline & Ripe & $\overline{\text { Green }}$ & & Ripe & Green & & \\
\hline Bounty & $18.7 \mathrm{bc}$ & $11.1 \mathrm{a}$ & $35.4 \mathrm{bc}$ & $12.3 \mathrm{ab}$ & $6.0 \mathrm{a}$ & $13.9 \mathrm{a}$ & $2.7 \mathrm{a}$ \\
\hline Chambly & $38.7 \mathrm{a}$ & $7.9 \mathrm{ab}$ & $26.0 \mathrm{c}$ & $10.4 \mathrm{ab}$ & $2.1 \mathrm{c}$ & $11.2 \mathrm{a}$ & $3.6 \mathrm{a}$ \\
\hline Glooscap & $28.7 \mathrm{ab}$ & $12.2 \mathrm{a}$ & $33.2 \mathrm{bc}$ & $13.6 \mathrm{ab}$ & $4.3 \mathrm{ab}$ & $5.5 \mathrm{a}$ & $2.5 \mathrm{a}$ \\
\hline Kent & $25.9 \mathrm{~b}$ & $3.5 \mathrm{bc}$ & $35.4 \mathrm{bc}$ & $17.0 \mathrm{a}$ & $2.6 \mathrm{bc}$ & $11.4 \mathrm{a}$ & $4.1 \mathrm{a}$ \\
\hline Midway & $20.6 \mathrm{bc}$ & $2.3 \mathrm{c}$ & $45.8 \mathrm{a}$ & $10.5 \mathrm{ab}$ & $1.0 \mathrm{c}$ & $14.5 \mathrm{a}$ & $5.4 \mathrm{a}$ \\
\hline Oka & $10.7 \mathrm{c}$ & $5.6 \mathrm{bc}$ & $56.0 \mathrm{a}$ & $8.1 \mathrm{~b}$ & $4.5 \mathrm{a}$ & $14.4 \mathrm{a}$ & $6.6 \mathrm{a}$ \\
\hline $\mathrm{LSD}_{0.01}$ & 12.1 & 4.5 & 19.3 & 7.8 & 1.8 & 9.5 & 4.3 \\
\hline
\end{tabular}

${ }^{\mathrm{z}}$ Average of four replications.

Table 3. Performance of six strawberry cultivars mechanically decapped using a Canners Machinery capper. $^{\mathrm{z}}$

\begin{tabular}{lcccc}
\hline \hline \multirow{2}{*}{ Cultivar } & \multicolumn{2}{c}{ Decapped mechanically $(\%)$} & Not decapped $(\%)$ & Nonmarketable $(\%)$ \\
\cline { 2 - 5 } Completely & Partially & 51 & 7 & 9 \\
Bounty & 30 & 75 & 3 & 20 \\
Chambly & 2 & 75 & 8 & 11 \\
Glooscap & 6 & 80 & 8 & 3 \\
Kent & 9 & 41 & 17 & 31 \\
Midway & 12 & 53 & 11 & 10 \\
Oka & 26 & &
\end{tabular}

${ }^{\mathrm{z}}$ Analysis of variance was not performed on these data because the four replications were mixed to obtain a large quantity of berries for mechanical dehulling.
'Glooscap', followed by 'Oka', 'Bounty', and 'Midway'. Many 'Midway' and 'Oka' fruit were not decapped mechanically and required manual dehulling (Table 3 ). This result suggests that none of the cultivars tested are suited for machine harvesting, and further breeding is required to produce improved adapted cultivars.

\section{Literature Cited}

Booster, D. 1980. Mechanical harvesting of strawberries in Oregon, p. 70-91. In: L.W. Martin and J.R. Morris (eds.). Strawberry mechanization. Oregon State Univ. Expt. Sta. Bul. 645.

Dale, A. 1983. Research report of progress, p. 8-37. In: 1983 Annual report for the project establishing a processing strawberry industry. Hort. Res. Inst. Ontario, Simcoe, Canada.

Denisen, E.L. and W.F. Buchele. 1967. Mechanical harvesting of strawberries. Proc. Amer. Soc. Hort. Sci. 91:267-273.

Hansen, C.M. and R.L. Ledebuhr. 1980. Mechanical harvesting of strawberries in Michigan, $\mathrm{p}$. 54-62. In: L.W. Martin and J.R. Morris (eds.). Strawberry mechanization. Oregon State Univ. Expt. Sta. Bul. 645.

Hecht, C. 1972. Mechanical picker for strawberries. U.S. Patent 3,698,171.

Khanizadeh, S. 1994. Breeding strawberries for eastern central Canada. Euphytica 77:45-49.

Khanizadeh, S., D. Buszard, and M.J. Lareau. 1992a Strawberry cultivar evaluation in Quebec. J. Small Fruit Viticult. 1(2):2.

Khanizadeh, S., D. Buszard, M.J. Lareau, and D. Bagnara. 1990. 'Chambly' strawberry. HortScience 25:984-985.

Khanizadeh, S. and M. Fanous. 1992. Mathematical indices for comparing small fruit crops and trait similarity. HortScience 27:346-348.

Khanizadeh, S., J. Fortin, M.J. Lareau, and D. Buszard. 1994. Sensory evaluation of six strawberry cultivars after machine harvest, p. 249254. In: H. Schmidt and M. Kellerhals (eds.). Progress in temperate fruit breeding. Kluwer Academic Publisher, The Netherlands.

Khanizadeh, S., M.J. Lareau, and D. Buszard. 1992b. Evaluation of advanced strawberry selections in Quebec. Fruit Var. J. 46(1):53-57.

Khanizadeh, S., M.J. Lareau, D. Buszard, and D. Bagnara. 1992c. 'Oka' Strawberry. HortScience 27:374-375

Lauro, E.M. 1986. Machinery and equipment, p. 29-40. Proc. Strawberry Res. Corp. Annu. Rpt. 1985. Hort. Res. Inst. Ontario, Simcoe, Canada.

Morris, J.R., A.A. Kattan, G.S. Nelson, and D.L. Cawthon. 1978. Developing a mechanized system for production, harvesting, and handling of strawberries. HortScience 13:413-422.

Ricketson, C.L. 1969. Plant spacing in solid-bed strawberry plantations. Rpt. Hort. Res. Inst. Ontario, Vineland, Canada.

SAS Institute. 1988. SAS/STAT, SAS/BASIC guide for personal computers. Version 6.04. SAS Institute, Cary, N.C.

Seecharan, R., M. Colwell, and G. Hergert. 1988. Estimated costs of mechanical strawberry harvesting. Can. Agr. Eng. 30(2):221-226.

Statistics Canada. 1991. Annual import book. Government of Canada, Ottawa, Ont. 